J. Clin. Chem. Clin. Biochem.

Vol. 22, 1984, pp. 47-51

\title{
Glycated Haemoglobin and Glycated Albumin: Evaluation of Different Methods in Diabetic Control
}

\author{
By Y. S. Shin, C. Stern, A. v. Rücker and W. Endres \\ Kinderklinik der Universität München
}

(Received June 6/October 13, 1983)

Summary: The levels of glycated haemoglobins and albumin were determined in 56 diabetic patients aged between 5 and 19 years. The glycohaemoglobin levels were measured by two different methods, cation-exchange chromatography and a colorimetric chemical method. The glycated albumin levels were measured by a chemical method in plasma albumin purified with Affi-gel Blue. The,results were compared with other indicators such as blood glucose and urinary glucose. The postprandial blood glucose levels were well correlated with the levels of glycoproteins: glycohaemoglobin by the column method $(r=0.886)$, glycohaemoglobin by the chemical method $(r=0.72)$ and glycoalbumin $(r=0.662)$. The urinary levels of glucose showed a weak correlation with blood glucose levels $(r=0.214)$ and with glycoalbumin $(r=0.298)$, but no correlation with glycohaemoglobin. Significant correlations between the changes of glycated albumin levels and glycohaemoglobin were found $(r=0.78)$. The result of the comparison of the chemical method with the column method for glycohaemoglobin determination showed a high correlation between the values $(r=0.95)$. There were significant differences in glycated protein levels between normal and diabetics. There were also significant differences in glycohaemoglobin and glycoalbumin values between fairly managed and poorly managed groups of diabetics. Of the three parameters, glycoalbumin, glycohaemoglobin and plasma glucose, the greatest absolute changes were found in the levels of glycoalbumin.

\section{Glykosyliertes Hämoglobin und glykosyliertes Albumin: \\ Erprobung verschiedener Methoden bei der Diabeteskontrolle}

Zusammenfassung: Bei 56 diabetischen Patienten im Alter zwischen 5 und 19 Jahren wurden die Konzentrationen des glykosylierten Hämoglobins und des glykosylierten Albumins ermittelt. Glykohämoglobin wurde sowohl mittels Kationenaustauscherchromatographie als auch mit einer kolorimetrischen chemischen Methode bestimmt. Das glykosylierte Albumin wurde nach Reinigung des Plasmaalbumins mit Affi-gel-Blue chemisch bestimmt. Die ermittelten Werte wurden mit den Blutglucosekonzentrationen und der renalen Glucoseausscheidung verglichen. Die postprandialen Blutglucosekonzentrationen korrelierten gut mit den Konzentrationen des säulenchromatographisch bestimmten $\mathrm{HbA}_{1}(r=0,886)$, denjenigen des chemisch bestimmten $\mathrm{HbA}_{1}(\mathrm{r}=0,72)$ und denjenigen des Glykoalbumins $(r=0,662)$. Es fand sich eine schwache Korrelation der Uringlucose mit der Blutglucose $(r=0,214)$ und dem Glykoalbumin $(r=0,298)$, aber keine mit $\mathrm{HbA}_{1}$. Die Konzentrationen des glykosylierten Albumins zeigten signifikante Korrelationen mit denjenigen von $\mathrm{HbA}_{1}(r=0,78)$. Eine starke Korrelation $(r=0,95)$ bestand zwischen den säulenchromatographisch und den chemisch bestimmten $\mathbf{H b A}_{1}$-Werten. Die Konzentrationen der glykosylierten Proteine der Diabetiker unterschieden sich signifikant von denjenigen der normalen Probanden. Das gleiche trifft für die Unterschiede zwischen gut und schlecht eingestellten Diabetikern zu, wobei die größte Trennschärfe mit der Bestimmung des glykosylierten Albumins erreicht wurde. 


\section{Introduction}

In conditions involving certain periods of hyperglycaemia, e.g. diabetes, levels of a variety of glycated proteins are increased (1-5). The major focus of nonenzymatic glycation in recent years has been on haemoglobin. Clinical studies have confirmed that the concentration of glycated haemoglobin $\left(\mathrm{HbA}_{1}\right)$ is a convenient indicator for not only the diagnosis of diabetes, but also for the control and progress of the disease $(1-3)$. Several researchers have recently described the relevance of measuring glycated serum protein and albumin $(4,5)$. Glycated albumin is reported to be more sensitive than glycohaemoglobin to changes in serum glucose (6). It has been generally accepted that glycated serum protein can serve as a short-term integrator of blood glucose homeostasis in diabetes, and $\mathrm{HbA}_{1}$ measurements as a long-term integrator (6-8). Various techniques have been described for the determination of glycated proteins such as cation-exchange chromatography (9-12), isoelectric focusing (13), a colorimetric chemical procedure $(14,15)$ and a radioimmunoassay $(16)$. In this study we investigated levels of $\mathrm{HbA}_{1}$ with two different methods, and glycated albumin levels with a single method in the ambulatory patients from our "Diabetic Clinic". We correlated the levels of glycated proteins with other indicators, such as blood glucose and urinary glucose.

\section{Materials and Methods}

\section{Patients}

180 samples from 56 insulin-dependent diabetics and 15 control subjects analysed over a 10 month period were selected for the study. The diabetic population included 22 boys and 34 girls with an average age of 13.5 years; the control group comprised 6 males and 9 females with an average age of 20 years. The diabetic groups were divided into three groups according to the physician's evaluation,

a fairly well controlled group (G1),

a group with average control (G2) and

a poorly managed group (G3).

The grouping was based on the average blood glucose levels and the renal glucose excretion.

Approximately $1-5 \%$ of total carbohydrates ingested were excreted as glucose in the urine in $\mathrm{G} 1$, in $\mathrm{G} 25-10 \%$ and in $\mathrm{G} 3$ over $10 \%$. Due to wide individual variation (see minimum and maximum data in tab. 1) the difference between the groups, especially between $\mathrm{G} 1$ and $\mathrm{G} 2$, is not very distinct.

Sample collection

Heparinized blood samples were centrifuged at $1500 \mathrm{~g}$ for 10 minutes and plasma was separated from the cells. The cells were washed three times with a $9 \mathrm{~g} / \mathrm{NaCl}$ solution and frozen at $-20^{\circ} \mathrm{C}$ until used. A portion of plasma was deproteinized with trichloroacetic acid within 20 minutes after venipuncture and the supernates were used for determination of glucose concentrations.
The remaining plasma was dialysed in $\mathrm{H}_{2} \mathrm{O}$ for 2 hours and used for the mesurement of glycated albumin. 24 hour urine samples ( 3 $\times 8$ hour portions) were collected prior to the withdrawal of blood, and frozen until used.

\section{Reagents}

Prefilled cation-exchange columns were eithèr from Bio-Rad Labs., U.S.A. (Bio-Rex 70, $0.6 \times 4 \mathrm{~cm}$ ) or from Boehringer Mannheim, F.R.G. (1 g per column, $0.6 \times 6 \mathrm{~cm}$ ). Testcombination kit for glucose determination was also from Boehringer; Affigel Blue (50-100 mesh; binding capacity, $9.5 \mathrm{mg} / \mathrm{ml}$ ) was from Bio-Rad Labs.; thiobarbituric acid and hydroxymethylfurfural were from Sigma Chemie, F.R.G.; and other chemicals from Merck, Darmstadt, F.R.G..

\section{Procedures}

\section{Measurement of glucose in urine and plasma}

Glucose levels in plasma and urine were measured with a hexokinase method adapted to a micro-procedure in our laboratory. The glucose levels were expressed in plasma as $\mathrm{mmol} / \mathrm{h}$ blood and glucose in urine as $\mathrm{g} / 24 \mathrm{~h}$.

\section{Determination of $H b A_{l}$ on a cation-exchange column}

Haemoglobin fractionation and quantitation were performed on mini resin columns of a weakly acidic carboxylic cation-exchanger. Washed erythrocytes $(0.1 \mathrm{ml})$ were haemolyzed in $0.5 \mathrm{ml}$ polyethyleneether (volume fraction 0.0033 ). After $15 \mathrm{~min}$ a 0.1 ml portion was chromatographed with $10 \mathrm{ml} 40 \mathrm{mmol} / \mathrm{l}$ phosphate buffer $\mathrm{pH} 6.7$ at $25^{\circ} \mathrm{C}$. Results are expressed as the fraction of the total haemoglobin chromatographed. Haemoglobin was determined colorimetrically by formation of cyanomethaemoglobin with $0.05 \mathrm{mmol} / 1 \mathrm{KCNO}$ and $0.2 \mathrm{~mol} / 1 \mathrm{~K}_{3}\left[\mathrm{Fe}(\mathrm{CN})_{6}\right]$.

Determination of $H b A$, by the chemical procedure

The assay procedure was according to the method described by Parker et al. (15). The fructose moiety of glycated haemoglobin is converted to 5 -hydroxymethylfurfural by heating with oxalic acid for $60 \mathrm{~min}$ in an autoclave at $125^{\circ} \mathrm{C}(5, \mu \mathrm{l}$ of washed erythrocytes in $0.1 \mathrm{ml} 0.3 \mathrm{~mol} / 1$ oxalic acid). The adduct formed by reacting $2-$ thiobarbituric acid with hydroxymethylfurfural is measured photometrically. A hydroxymethylfurfural solution containing 40 $\mu \mathrm{mol} / \mathrm{l}$ was used as a standard. The results were expressed as hydroxymethylfurfural formed, nmol/mg $\mathrm{Hb}$.

Tab. 1. Clinical features and glucose concentrations in blood and urine.

\begin{tabular}{|c|c|c|c|c|}
\hline Subjects & $\begin{array}{l}\text { Age } \\
\text { (years) }\end{array}$ & $\mathbf{n}$ & $\begin{array}{l}\text { Postprandial } \\
\text { blood glucose } \\
(\mathrm{mmol} / \mathrm{l})\end{array}$ & $\begin{array}{l}\text { Urine glucose } \\
(\mathrm{g} / 24 \mathrm{~h})\end{array}$ \\
\hline Normal & $1-40$ & 15 & $6.2^{\mathrm{a}}(5.3-6.8)^{\mathrm{b}}$ & n.d.c \\
\hline \multicolumn{5}{|c|}{ Diabetics } \\
\hline $\begin{array}{l}\text { G1 } \\
\text { G2 } \\
\text { G3 }\end{array}$ & $\begin{array}{l}5-17 \\
7-19 \\
9-19\end{array}$ & $\begin{array}{l}16 \\
11 \\
29\end{array}$ & $\begin{array}{r}6.7(4.7-14.8) \\
12.2(4.7-14.6) \\
15.2(7.1-25.8)\end{array}$ & $\begin{array}{l}12.1^{\mathrm{a}}(0-27.1)^{\mathrm{b}} \\
17.4(6.5-35) \\
62.9(12.9-128)\end{array}$ \\
\hline Total & $5-19$ & 56 & $12.1(4.7-25.8)$ & $28.9\left(\begin{array}{ll}0 & -128.1)\end{array}\right.$ \\
\hline
\end{tabular}

a median b range c n.d.: not determined
G1: fairly managed group
G2: averagely managed group
G3: poorly managed group




\section{Determination of glycated plasma albumin}

Human serum albumin was purified by affinity chromatography on Affi-gel Blue. A $0.7 \mathrm{ml}$ column was equilibrated with $1.5 \mathrm{ml}$ $0.02 \mathrm{~mol} / \mathrm{h} \mathrm{Na-phosphate} \mathrm{buffer,} \mathrm{pH} 7.1$. Plasma $(0.2 \mathrm{ml})$ was chromatographed with $1.0 \mathrm{ml}$ of the buffer and then with $1.5 \mathrm{ml}$ of the buffer containing $1.4 \mathrm{~mol} / \mathrm{NaCl}$. The $\mathrm{NaCl}$ fraction was used for the determination of glycated albumin. The column was regenerated with $2 \mathrm{ml} 8 \mathrm{~mol} / \mathrm{h}$ urea and used again. Glycated albumin was detected using the thiobarbituric acid procedure of Flücker \& Winterhalter (14) which measures hydroxymethylfurfural released upon hydrolysis of ketoamine adducts of protein. Protein was determined by a modified method (16) of Lowry et al. (17).

\section{Data analysis}

The unpaired Student's t-test was used to compare means of different subpopulations, and the slopes of regression lines were compared by the standard statistical method. When the data were not normally distributed, median, Spearman $r_{s}$ correlation coefficient and the Mann \& Whitney test were used for intergroup comparisons (18).

\section{Results}

As shown in figure 1a, only a weak correlation was observed between blood glucose levels and urinary glucose levels. However, some increments were seen in urinary levels with increased concentrations of blood glucose levels. The values for glycated haemoglobins and glycated albumin in normal subjects and diabetics are shown in table 2 . In table 3 the statistical significance ( $P$ values) of the differences in various parameters are summarized. There were significant differences in glycated haemoglobins as well as glycated albumin levels between normal subjects and diabetics (tabs. 2 and 3), but not in postprandial glucose levels in blood (tabs. 1 and 3). Comparison of $\mathrm{HbA}_{1}$ levels between the various diabetic groups revealed a considerable difference, except between G2 and G3. Correlations of postprandial blood glucose levels with other various parameters are shown in figures $1 \mathrm{a}-1 \mathrm{~d}$. Strong correlations were found between blood glucose levels and both glycated haemoglobin and albumin levels. The proportional increase in glycated proteins was greater than the percent increase in postprandial blood glucose (fig. 1d). Blood glucose levels increased by $40 \%$, while the increments in glycated proteins were about $100 \%$. No correlation was found between the urinary glucose levels and $\mathrm{HbA}_{1}$ values, however, some correlations were observed between changes in urinary glucose levels and glycated albumin values.

As shown in figures $2 a-2 c$ there were significant correlations between changes in $\mathrm{HbA}_{1}$ levels and glycated albumin levels. The greater absolute change was found in glycations of albumin compared with haemoglobin, i.e., the $\mathrm{HbA}_{1}$ increments were about $57 \%$ while glycated albumin increased by 2 units to
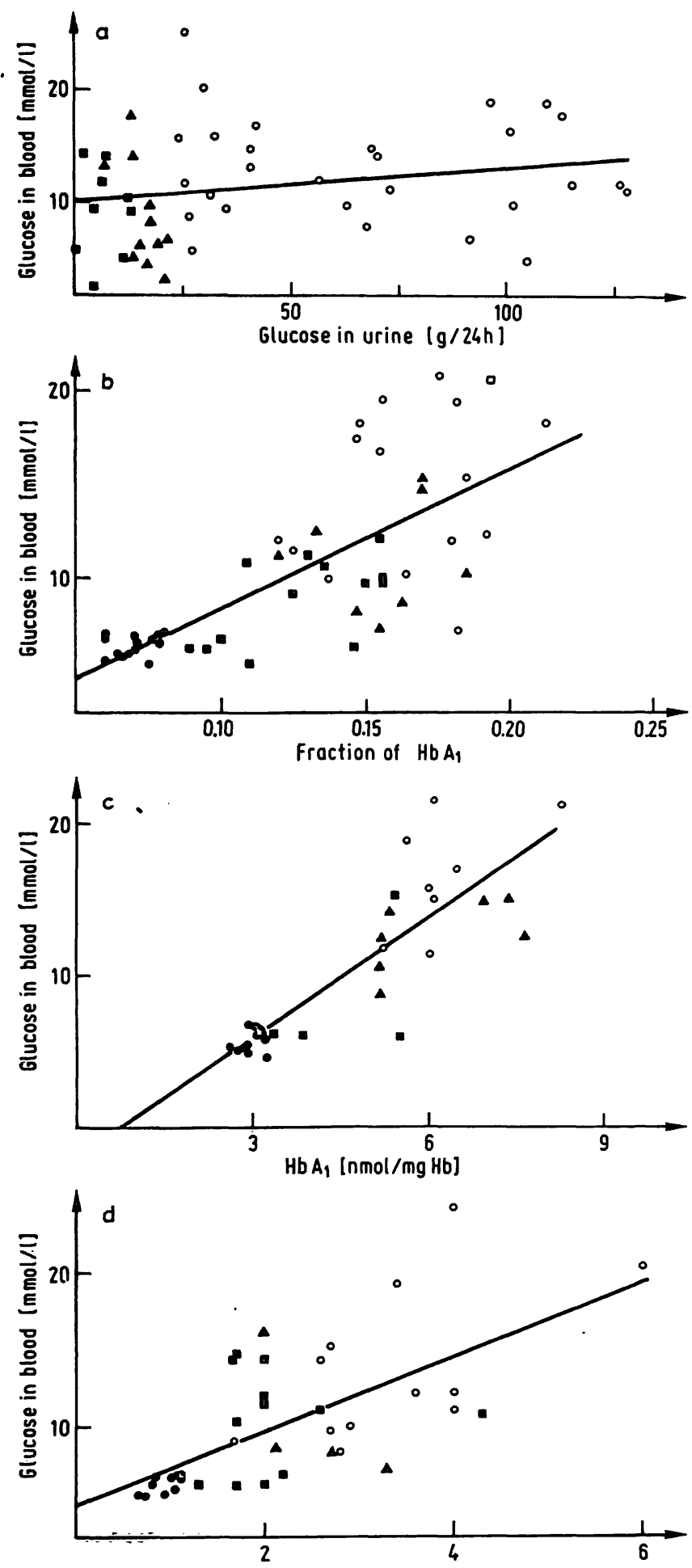

Glycated albumin [hydroxymethylfurfural, nmol/mg protein]

Fig. 1. Correlations between changes in postprandial blood glucose levels and other parameters: $A$, urinary glucose levels; $\mathrm{B}, \mathrm{HbA}_{1}$ levels by the column method; $\mathrm{C}, \mathrm{HbA}_{1}$ levels by the chemical method; $D$, glycated albumin levels.

$A: y=10.59+0.027 x, r=0.214$

B: $y=0.96+0.73 x, \quad r=0.72$.

C: $y=1.44+2.47 x, \quad r=0.85$

$D: y=4.8+2.45 x, r=0.662$

, normal; $\square, \mathrm{Gl} ; \Delta, \mathrm{G} 2 ; \mathrm{O}, \mathrm{G} 3$.

$4(100 \%)$. Comparison of values from the column method and the chemical method for $\mathrm{HbA}_{1}$ showed an excellent correlation $(r=0.95)$. 


\section{Discussion}

In recent years, in the field of diabetes, interest has been focused on the glycation of haemoglobin (13 ), albumin (4-6), lipoprotein (19), and peptides (20). It has been reported that glycohaemoglobin provides an index of the patient's average blood glucose concentration over a long-time period, and glycoalbumin a relatively short-term period $(6-8)$. The present data confirm that $\mathrm{HbA}_{1}$ as well as glycoalbumin are well correlated with changes in the blood glucose concentration (fig. 1). Although postpran-
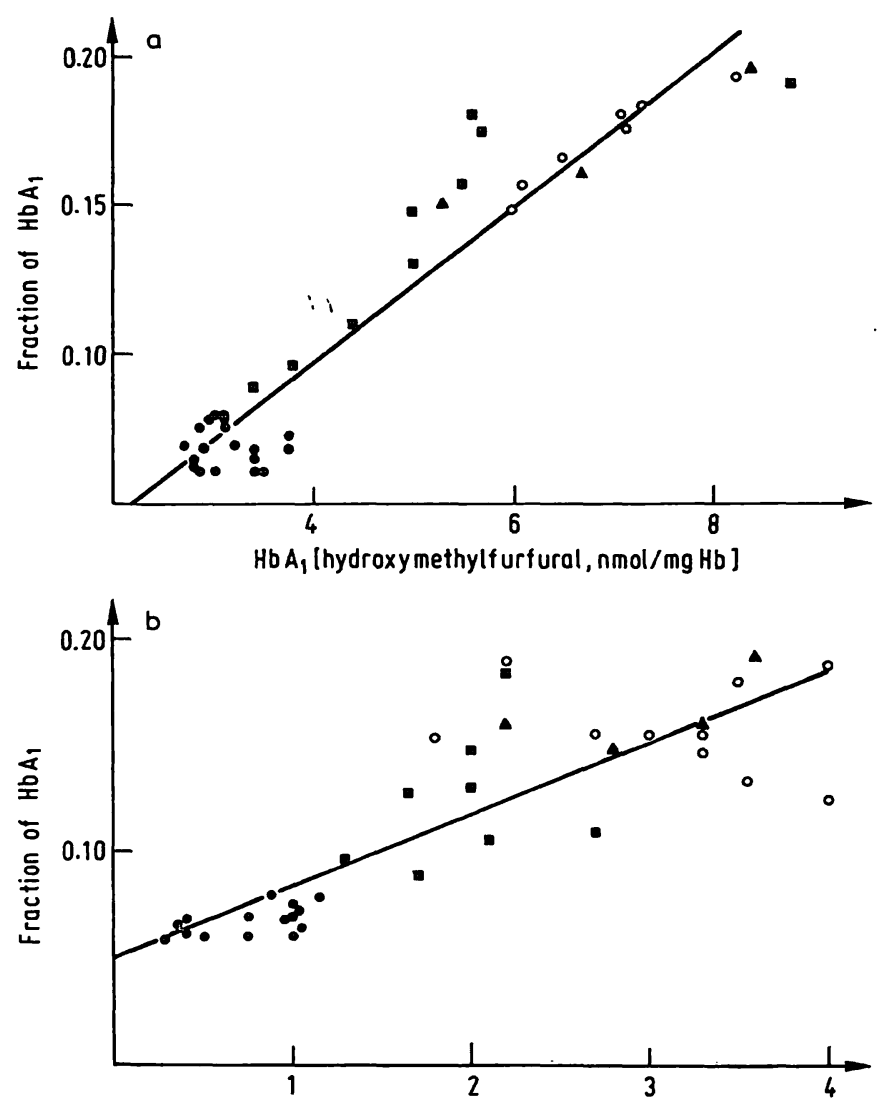

Glycated albumin [hydroxymethylfurfural, nmol/mg protein]

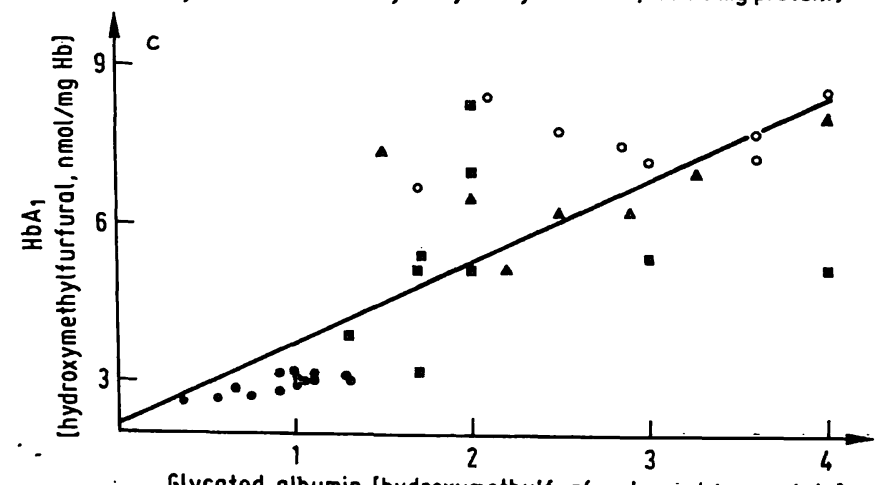

Glycated albumin [hydroxymethylfurfural, nmol/mg protein]

Fig. 2. Correlations between changes in glycated proteins.

a: $\mathrm{HbA}_{1}$ by the column method vs. $\mathrm{HbA}_{1}$ levels by the chemical method. $\mathrm{y}=-0.58+2.57 \mathrm{x}, \mathrm{r}=0.95$.

$\mathrm{b}: \mathrm{HbA}_{1}$ levels by the column method vs. glycated albumin levels. $y=5.03+3.38 x, r=0.843$.

c: $\mathrm{HbA}_{1}$ levels by the chemical method vs. glycated albumin levels. $\mathrm{y}=2.17+1.55 \mathrm{x}, \mathrm{r}=0.783$.

๑, normal; $\mathbf{B}, \mathrm{G} 1 ; \Delta, \mathrm{G} 2 ; \mathrm{O}, \mathrm{G} 3$. dial blood glucose was investigated it can be seen that glycoproteins reflect the blood glucose levels. Goldstein et al. (21) reported that approximately 9$11 \%$ of $\mathrm{HbA}_{1 \mathrm{c}}$ could reflect very recent changes in blood glucose levels. In view of the short half-life of albumin (2-3 weeks) we can assumerthat a higher fraction of glycoalbumin reflects recent changes in blood glucose levels. Contrary to recent reports (22, 23), the amount of glucose in the urine was only weakly correlated with glycated protein levels. This may well be due to the short collection period (over a 24 hour-period) or due to other factors (24). Gabbay et al. (25) reported that glucose levels in the urine collected 2 months prior to the determination were well correlated with glycohaemoglobin values. It is, therefore, not surprising to find only a weak correlation between glycoalbumin levels and the urinary glucose values. However, the most interesting observation is that there was very little overlap of glycoprotein values between the normal and diabetic groups (fig. 2), in contrast with blood glucose (fig. 1). Furthermore, there was also very little overlap of the measurements of glycoproteins, especially of glycated albumin, between fairly well controlled and poorly managed diabetic groups. From these results we can conclude that the measurements of glycated proteins are important in diabetes as more reliable and stable integrators than blood glucose or urinary glucose determinations. Among various methods for glycohaemoglobin measurement, the chemical method which measures a stable ketoform of $\mathrm{HbA}_{1}$, offers an inexpensive rapid procedure. The mini cation $\mathrm{CO}^{-}$ lumn method which measures a làbile form of $\mathrm{HbA}_{1}$ as well, may, on the other hand, be better for determinations which reflects recent changes in blood glucose levels. The glycoalbumin determination involves an affinity chromatography step for the isolation of plasma albumin. Although we found a very good correlation between the increments of glycoalbumin and glycoprotein levels in plàsma, it may be helpful to determine specifically glycoalbumin, in view of the reports of albumin deposition in basal membranes (26) and possible roles of glycated albumin in microangiopathy (23). Furthermore, the greatest absolute changes in glycoalbumin in comparison with those in glycohaemoglobin or plasma glucose (figs. 1 and 2) again indicate the measurement of glycoalbumin to be a sensitive index for the diabetic control.

In conclusion, routine determinations of glycated proteins are valuable for the physicians in diabetic clinics not only for the dietary management of the patients, but also for a better understanding of the pathogenesis of disease. 
Tab. 2. Glycated haemoglobin $\left(\mathrm{HbA}_{1}\right)$ measured by cation-exchange column chromatography and by the colorimetric method, and glycated albumin in diabetic children and normal subjects.

\begin{tabular}{|c|c|c|c|c|c|c|c|}
\hline \multirow[t]{2}{*}{ Subject } & \multirow[t]{2}{*}{$\mathrm{n}$} & \multicolumn{2}{|c|}{$\begin{array}{l}\mathrm{HbA}_{1} \\
\text { (\% of total haemoglobin) }\end{array}$} & \multicolumn{2}{|c|}{$\begin{array}{l}\mathrm{HbA}_{1} \\
\text { (hydroxymethylfurfural, } \\
\text { nmol/mg haemoglobin) }\end{array}$} & \multicolumn{2}{|c|}{$\begin{array}{l}\text { Glycated albumin } \\
\text { (hydroxymethylfurfural, } \\
\text { nmol/mg protein) }\end{array}$} \\
\hline & & Range & Median & Range . & Median & Range & Median \\
\hline $\begin{array}{l}\text { Normal } \\
\text { Diabetics }\end{array}$ & 15 & $5.9-7.9$ & 6.8 & $2.00-3.30$ & 2.94 & $0.28-1.35$ & 1.00 \\
\hline $\begin{array}{l}\text { G1 } \\
\text { G2 } \\
\text { G3 }\end{array}$ & $\begin{array}{r}14 \\
8 \\
21\end{array}$ & $\begin{array}{r}9.6-18.4 \\
12.5-19.2 \\
11.7-21.6\end{array}$ & $\begin{array}{l}14.6 \\
16.7 \\
16.6\end{array}$ & $\begin{array}{l}3.31-5.70 \\
5.20-7.70 \\
5.10-8.30\end{array}$ & $\begin{array}{l}5.45 \\
5.30 \\
6.10\end{array}$ & $\begin{array}{l}0.80-4.50 \\
1.50-4.00 \\
1.23-6.80\end{array}$ & $\begin{array}{l}2.00 \\
2.60 \\
2.80\end{array}$ \\
\hline Total & 43 & $9.6-21.6$ & 15.8 & $3.30-8.30$ & 5.70 & $0.80-6.80$ & 2.20 \\
\hline
\end{tabular}

G1: fairly well managed group

G2: group with average control

G3: poorly managed group

Tab. 3. Statistical significance (Mann \& Whitney test) of the differences in various parameters between normal and diabetic groups.

\begin{tabular}{|c|c|c|c|c|c|}
\hline \multirow[t]{2}{*}{ Group } & \multicolumn{2}{|l|}{ Glucose } & \multicolumn{2}{|l|}{$\mathrm{HbA}_{1}$} & \multirow{2}{*}{$\begin{array}{l}\text { Glyco- } \\
\text { albumin }\end{array}$} \\
\hline & Blood & Urine & Column method ${ }^{a}$ & Chemical method & \\
\hline Normal vs. diabetics & $P<0.025$ & - & $P<0.001$ & $P<0.001$ & $P<0.001$ \\
\hline Normal vs. G1 & n.s. ${ }^{c}$ & - & $P<0.001$ & $P<0.001$ & $\mathrm{P}<0.001$ \\
\hline G1 vs. $G 2$ & n.s. ${ }^{c}$ & n.s. ${ }^{c}$ & $P<0.05$ & $P<0.01$ & $\mathrm{P}<0.05$ \\
\hline G1 vs. G3 & $P<0.001$ & $P<0.001$ & $P<0.01$ & $\mathrm{P}<0.01$ & $\mathrm{P}<0.001$ \\
\hline G2 vs. G3 & n.s.c & $P<0.005$ & n.s. ${ }^{c}$ & n.s..$^{c}$ & n.s..$^{c}$ \\
\hline
\end{tabular}

a cation column chromatographic method

b chemical photometric method

c not significant

\section{References}

1. Koenig, R. J., Peterson, C. M., Jones, R. L., Saudek, C., Lehrman, M. \& Cerami, A. (1976) N. Engl. J. Med. 295, 417-420.

2. Bunn, H. S., Gabbay, K. H. \& Gallop, P. M. (1978) Science 200, 21-27.

3. McDonald, J. M. \& Davis, J. E. (1979) Hum. Pathol. 10, 270-291.

4. Dolhofer, R. \& Wieland, O. H. (1979) FEBS Lett. 103, 282-286

5. Guthrow, C. E., Morris, M. A., Day, J. F., Thorpe, S. R. \& Baynes, J. W. (1979) Proc. Natl. Acad. Sci. USA 76, 42584261.

6. Day, J. F., Ingebretsen, C. G., Ingebretsen, jr. W. R., Baynes, j. W. \& Thorpe, S. R. (1980) Diabetes 29, 524-527.

7. Dunn, P. J., Cole, R. A., Soeldner, J. S. \& Gleason, R. E. (1981) J. Clin. Endocrinol. Metab. 52, 1019-1022.

8. Inada, M., Oishi, M., Nishikawa, M., Kurata, S. \& Imuva, H. (1980) Endocrinol. Japon. 27, 411-415.

9. Kynoch, P. A. M. \& Lehmann, H. (1977) Lancet II, 16.

10. Davis, J. E., McDonald, J. M. \& Jarret, L. (1978) Diabetes 27, $102-107$.

11. Cole, R. A., Soeldner, J. S., Dunñ, P. J. \& Bunn, H. E. (1978) Metabolism 27, 289-301.

12. Abraham, E. C., Huff, T. H., Cope, N. D., Wilson, J. B., Bransome, E. D. \& Huisman, H. J. (1978) Diabetes 27, 931-937.

13. Schoos, R., Schoos-Barbette, S. \& Lambotte, C. (1978) Clin. Chim. Acta 86, 61-65.

14. Flücker, R. \& Winterhalter, K. H. (1976) FEBS Lett. 71, $356-360$.
15. Parker, K. M., England, J. D., Da Costa, J., Hess, R. \& Goldstein, D. E. (1981) Clin. Chem. 27, 669-672.

16. Shin-Buehring, Y., Dallinger, M., Osang, M., Rahm, P. \& Schaub, J. (1980) Biol. Neonate 38, 300-308.

17. Lowry, O. H., Rosebrough, N. J., Farr, A. L. \& Randall, R. J. (1951) J. Biol. Chem. 193, 265-275.

18. Sachs, L. (1972) Statistische Auswertungsmethoden, Springer-Verlag Berlin, 230-236.

19. Schleicher, E., Deufel, T. \& Wieland, O. H. (1981) FEBS Lett. 129, 1-4.

20. Brownlee, M., Vlassara, H. \& Cerami, A. (1980) Diabetes 29, 1044-1047.

21. Goldstein, D. E., Peth, S. B., England, J. D., Hess, R. L. \& Da Costa, J. (1980) Diabetes 29, 623-628.

22. Williams, M. L. \& Savage, D. C. L. (1979) Arch. Dis. Child. 54, 295-298.

23. Wälinder, O., Wibell, L. \& Tuvemo, T. (1980) Diabète et Metabolisme 6, 251-255.

24. Williams, S. K., Devenny, J. J. \& Bitensky, M. W. (1981) Proc. Natl. Acad. Sci. USA 70, 2393-2397.

25. Gabbay, K. H., Hasty, K., Breslow, R., Ellison, C., Bunn, H. F. \& Gallop, P. M. (1978) J. Clin. Endocrinol. Metab. 44, 859.

26. Chavers, B., Etzwiller, D. \& Michael, A. F. (1981) Diabetes $30,275-278$.

Y. S. Shin, Ph. D.

Universitäts-Kinderklinik

Lindwurmstraße 4

D-8000 München 2 
. 